\title{
Two Cases Illustrating the History of Algebraic Expressions
}

\author{
Eleonora Sammarchi (Université Paris Diderot, France)
}

\section{Introduction}

If we consider a polynomial as an algebraic expression composed of two, three or several added and/or subtracted terms, we might imagine that its conception is as old as the theory of equations itself. On the contrary, analysis of medieval and early modern writings dealing with algebraic computations shows that the definition of the mathematical features of this expression is far from being immediately evident: it requires a prior systematisation of the theory of algebraic computations and a deep investigation of the notions of number and operation. Therefore, polynomials seem to be conceived quite late in the history of algebra. From the point of view of mathematical terminology, this is supported by the fact that the first occurrences of the French word polynome and of the Latin word polinomius are attested in seventeenth-century writings. ${ }^{1}$

For a long time, algebraists manipulated a generic object which presented its own peculiarities, but also shared several features of what would later become a polynomial. In order to reconstruct the origins of this fundamental object of algebra, research needs to focus on the lexical choices made by some of these medieval and early modern algebraists. What terms did scholars use for their algebraic expressions? And what kind of object did these terms designate?

In the following sections, I present two results of my research into the history of algebraic expressions. The first case considered is that of the school of arithmeticianalgebraists inspired by the writings of the mathematician al-Karaji . This school flourished in the eastern part of the Arab-Islamic Empire between the end of the tenth and the thirteenth century. The second concerns the German Cossic tradition, which includes the sixteenth and seventeenth-century generations of Rechenmeister (masters of computations).

It was decided to compare these two traditions because, although they belong to two different times and places, they developed the same interest in the relation between algebra and arithmetic, and they seem to have had a common pragmatic attitude towards the way in which they conceived their algebraic expressions. Both the Arabic and the German masters aimed to develop the technical aspects of algebra rather than to investigate the nature of the entities engaged in these techniques.

\footnotetext{
1 We find the term "polynomial" in Cyriaque de Mangin's Cursus mathematicus (1634); Jacques Ozanam's Dictionnaire mathématique (1691); and Fantet de Lagny's Nouveaux éléments d'arithmétique et d'algèbre (1697).
}

\section{Al-Karajī's school of arithmetician-algebraists}

One of the major accomplishments of ninth-century algebraists such as al-Khwārizmī and Abū Kāmil was the elaboration of a theory for second-degree equations that could be applied in order to solve both geometrical and arithmetical problems. Once this theory was established, algebraists redirected their interest to new topics. By the end of the tenth century, the mathematician al-Karaji chose to investigate the interaction between arithmetic and algebra, and began to create a coherent and exhaustive system of rules for calculating with algebraic entities. His work gave rise to a new tradition of arithmetician-algebraists, whose aim was to improve algebra with the help of arithmetic and viceversa. This tradition focused on the notion of operation, and its aim was to make the algebraist able to manipulate unknown quantities as the arithmetician manipulates known ones.

Al-Karajī's research was then improved upon by the twelfth-century scholar al-Samaw'al (d.1135). In the middle of the thirteenth century, the Persian mathematician al-Zanjānī followed this same tradition, and his Qistās al-mu'ādala fī 'ilm al-jabr wa'l-muqābala (Balance of the equation in the science of algebra and muqābala) accurately recalls and elaborates upon al-Karajī's work.

\section{Algebraic powers}

In the presentation of the rules for algebraic operations, unknown quantities are considered as either simple or composed entities. The basic terms are the algebraic powers. These are defined by al-Zanjānī as follows:

A thing (shay') multiplied by itself is called a root, and the result [of the multiplication] is a square [...] The product of the root by the square is a cube, and by the cube a square-square, and by the square-square a square-cube, and by the square-cube a cube-cube, and by the cube-cube a square-square-cube, and so on. If the root is two, the square is four, the cube is eight, the square-square is sixteen, the square-cube is thirty-two, the cube-cube is sixty-four and the square-squarecube a hundred and twenty-eight. ${ }^{2}$

\footnotetext{
2 Al-Zanjānī, Balance of the equation, translated from [2], fol. 2r-v. This definition owes its origins to Diophantus, whose arithmetical books were translated into Arabic in the second half of the ninth century by Qustā ibn Lūqā and represented an important reference for the algebraic-arithmetical tradition. Al-Zanjānī took the definition and the numerical example cited here from al-Karajī's treatise al-Fakhrī .
} 


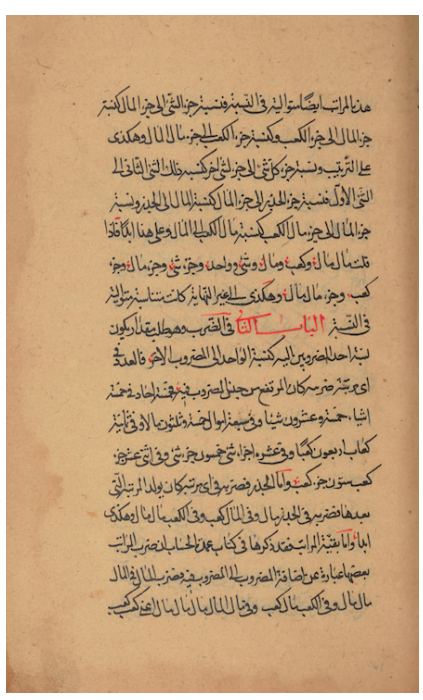

Fig. 1. Al-Zanjānī's Balance of the equation, fol. $4 \mathrm{r}$. The word 'ibāra ("expression") appears at line 16.

\section{Simple vs. composite numbers, magnitudes and expressions}

If we examine the lexicon of the arithmetician-algebraists' treatises, al-Karajì's school did not have a technical word that specifically designated their algebraic expressions. Since algebra was conceived as an art that allows manipulation of geometrical as well as arithmetical quantities, they sometimes referred to these objects as simple/composite numbers ('adad) or as simple/composite magnitudes (miqdār). ${ }^{3}$

Another interesting choice made by these authors, especially by al-Karajī and al-Zanjānī, is the use of terminology that comes from the field of linguistics. The implicit analogy is between a sentence as a concatenation of words and an algebraic expression as an aggregate of algebraic terms. Thus, we find in the texts the use of laft ("term") or of jumla mufrad ("simple sentence") in order to designate a single unknown quantity, and the use of jumla or of 'ibāra ("phrase", "expression") for a multi-terms aggregate. One example of this terminology occurs in al-Karajī's introduction of the algebraic addition:

Add two expressions (jumlatain), of one, two or several genres. The rule for this is that you juxtapose each genre to its genre. Example: add five things and four squares to three things and three squares. Add five things to three things: this makes eight things, and four squares to three squares: this makes seven squares. Hence, the sum is eight things plus seven squares. ${ }^{4}$

\footnotetext{
${ }^{3}$ In this tradition the term "magnitude" is also applied to the numbers. Hence, it loses its geometrical sense and can be translated as "quantity".

${ }^{4}$ Al-Karajī , al-Fakhrì fí șinā'at al-jabr wa'l-muqābala (Book of al-Fakhrī on the art of algebra and muqābala), translated from [7], p. 118.
}

Another example is found in al-Zanjānī's explanation of the multiplication of two ranks:

The product of two ranks is an expression ('ibāra) obtained by the application of the multiplicand to the multiplicator. The product of the square by the square is a square-square, and by the cube it is a square-cube, and by the square-square it is a square-square-square, I mean a cube-cube. [...] The rule is that you combine the terms (pl. of laft) of the multiplicand to the terms of the multiplicator and you first mention the smaller one. ${ }^{5}$

\section{On the mathematical features of the expressions}

The lack of specific terminology is probably due to the fact that the algebra of these texts is conceived in ordinary language. Moreover, these scholars concentrated on improving the technical aspects of algebraic computations, and paid very little attention to more epistemological questions about the nature of the objects they were working with. This non-philosophical attitude was quite frequent at the time, and especially in a milieu like that of these arithmeticians. In these texts, there is no explicit definition of what an expression is in the field of the arithmetic of the unknowns. However, if we examine the examples and the problems in which such expressions are employed, we can identify the mathematical peculiarities presented by these aggregates.

\section{Inverses of powers}

The first significant difference with regard to the notion of polynomial is that expressions can include the inverses of powers. For instance, in his treatise al-Bāhir fì' l-jabr (The brilliant in algebra), al-Samaw'al gives a tabular method for the extraction of the square root of the following composed magnitude:

25 cube-cube plus nine squares-square plus 84 squares plus 64 units plus a hundred part of a square plus 64 part of a square-square minus 30 square-cube and 40 cube and 116 thing and 48 part of a thing and 96 part of a cube. ${ }^{6}$

This can be transcribed as follows:

$25 x^{6}+9 x^{4}+84 x^{2}+64+100 \frac{1}{x^{2}}+64 \frac{1}{x^{4}}-30 x^{5}-40 x^{3}-116 x-$ $48 \frac{1}{x}-96 \frac{1}{x^{3}}$.

\section{Numeral adjectives}

As was previously mentioned, the algebra of these texts is conceived in natural language. When we analyse the algebraic expressions, we can see that what we call the coefficient of a term corresponded for al-Karajì's school

\footnotetext{
5 Al-Zanjānī, Balance of the equation, translated from [2], fol. $4 \mathrm{r}$.

6 This exercise is discussed by Roshdi Rashed in [1], p. 32-24. As can be seen, al-Samaw'al uses a mixed form for writing the numbers: sometimes they are written in numerals, sometimes they are written out in letters.
} 
to a numeral adjective. Hence, it was interpreted as a counting number. For instance, in the equation: "Three squares plus ten things equal thirty-two units", which we could transcribe as $3 x^{2}+10 x=32$, "three" and "ten" are "the number of squares" and "the number of things". They are conceived as a multitude of squares or things, as 32 is a multitude of units. ${ }^{7}$ For this reason, irrational numbers are accepted as solutions of the equation, but they are not conceivable as a "number of things". However, it is difficult to determine whether we can speak of coefficients in these texts or not. Indeed, this concept seems to change when these authors use tabular methods in order to solve, for instance, the division of two composed magnitudes or the extraction of square root of an expression, as in al-Samaw'al's exercise. In these cases, numeral adjectives are directly employed and manipulated in a tabular computation. Hence, they seem to share some of the features of modern coefficients, and acquire an autonomous status in comparison to the unknown quantity.

\section{Subtracted quantities}

In this arithmetic of the unknowns, although the rule of signs for the multiplication and the subtraction are already known, it is not correct to qualify the quantities as positive or negative: there can only be added or subtracted terms. Indeed, as al-Samaw'al's exercise shows, a simple or composed expression never starts with a minus-term: subtracted terms are always listed at the end of the expression, after the quantity from which they are subtracted. Moreover, since negative arithmetical numbers did not exist, negative solutions are not yet considered as solutions of algebraic problems.

\section{The German Cossic tradition}

The expressions considered by al-Karajī's tradition can be of $n$-degree. But when two expressions are put together in order to compose an equation, the degree of the latter is never greater than 2. During the Italian Renaissance, algebraists developed a theory of cubic (and quartic) equations solved by arithmetical tools. In this field, Gerolamo Cardano's Ars Magna is one of the texts that had a significant impact on the German-speaking arithmetic masters of subsequent generations. Cardano's list of equations and the rules (Regulae) that he presented in order to solve them were discussed, although often not correctly understood, by the so-called Cossic tradition. The word $\operatorname{Co} \beta$ derives from the Italian $\cos a$, which translated the Arabic word shay' ("thing"). It denotes the unknown quantity and, by extension, algebra as a

\footnotetext{
7 Jeffrey Oaks clarified this point in [5]. He noticed the fact that, in Arabic texts, the term "coefficient" does not exist. Instead, these scholars worked with literal collections of squares, things etc. In his article, Oaks presents what he calls the "aggregations interpretation", according to which "the two sides of an Arabic equation are not linear combinations in the modern sense, but are collections of the algebraic powers, in which all mathematical operations have already been performed". This is also an interesting observation from our present point of view.
}

theory of equations. The members of this tradition were sixteenth and seventeenth-century Rechenmeister, especially those who worked in Ulm and Nuremberg.

As Ivo Schneider has pointed out, ${ }^{8}$ the success of the Rechenmeister school was directly related to the rise of the new bourgeoisie, who needed private teachers of mathematics, and especially arithmetic, for their children. Christoph Rudolff's Behend und hübsch Rechnung durch die kunstreichen Regeln Algebre, so gemeinicklich die Coß genennt werden (1515), Adam Ries's Die Co $\beta$ (1524) and Michael Stifel's Arithmetica integra (1544) were three fundamental texts of the sixteenth-century Cossic tradition. Their work was then commented on and improved in the seventeenth century by a new generation of masters, among whom Peter Roth and Johannes Faulhaber are pre-eminent.

\section{Stifel's "Cossic numbers"}

For the Cossic tradition, algebra is part of arithmetic. This subordination is clearly stated in Stifel's Arithmetica Integra. According to Stifel, there are three types of numbers, which constitute the main topics of the three books of the Arithmetica Integra:

- rational numbers are the numbers of the arithmetic of integers and fractions (Book I, De algorithmo numerorum integrorum et minutiarum $)^{9}$;

irrational numbers are the numbers of the arithmetic of radicals (Book II, De essentia numerorum irrationalium);

- Cossic numbers are the numbers of the arithmetic of unknown quantities (Book III, De Regula Algebrae, Section III, De algorithmo numerorum cossicorum).

The definition of a Cossic number is given at the very beginning of Section III:

Cossic numbers are numbers denominated proportional to a geometrical progression. ${ }^{10}$

Stifel designated each algebraic power with a specific symbol (see Fig. 2). This symbolic writing of variables relies on that of Cardano and constitutes a significant innovation in early modern algebra.

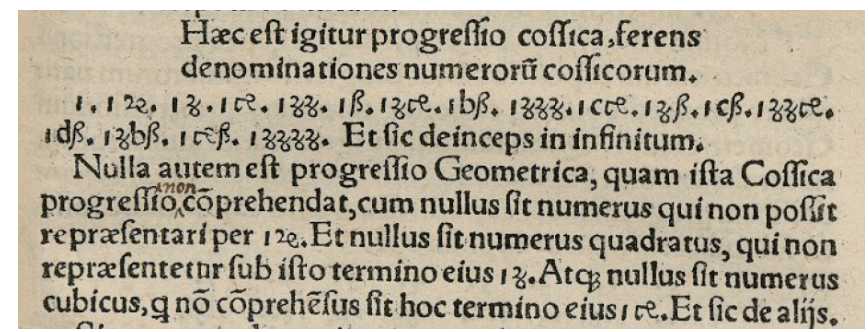

Fig. 2. Stifel's representation of Cossic numbers.

\footnotetext{
8 See [8].

9 Sabine Rommevaux-Tani clarified in [6] that, for Stifel, an algorithmo is an explanation of how to write the numbers and how to add, subtract, multiply and divide them.

${ }^{10}$ Stifel, Arithmetica Integra, translated from [9], fol. 234r.
} 


\section{Simple and composed Cossic numbers}

As with the Arabic expressions, Cossic numbers can be simple (simplices), like $20 x$ and $30 x^{2}$, composed (compositi), like $x+x^{2}$, or diminished (diminuti), like $2 x-8$. Moreover, since the theory of equations has a primary role in the German texts, simple and composed Cossic numbers are directly conceived in the framework of an equation. Hence, they are either two or three-term aggregates.

\section{Seventeenth-century "Cossic quantities"}

In Peter Roth's Arithmetica Philosophica (1608) and Johannes Faulhaber's Academia Algebrae (1622), the language of arithmetic books shifts from Latin to German. In the new texts, numero cossico is replaced by idioms that are less arithmetically denoted, such as "Cossic quantity" (Cossische Quantitet) and "Algebraic quantity" (Algebraische Quantitet).

Another term which we can already find in Cardano's writings, is Aggregaten, or its Latin version Aggregata (in both cases, it is always used in the plural). It originally designates the result of a numerical sum. However, since, as we have mentioned, there are several types of numbers for the Cossic tradition, and algebraic numbers are one of these types, Aggregaten is also employed in the field of algebra, where it refers to a composed algebraic quantity.

We can find these three lexical choices juxtaposed in one of the problems (Quaestionen, see Fig. 3) included in Faulhaber's Academia Algebrae:

There are several aggregates of $D$-sursolit numbers ${ }^{11}$ formed by addition, following each other in the right order (so that nothing is left out), and they make together the sum 70322010. How many are they? And what are the algebraic quantities [that] are naturally said equal to this just set number according to a regular computation? The answer of the Aggregates is 4 . And [this] is the desired Cossic quantity: $6 x^{15}+90 x^{14}+$ $525 x^{13}+1365 x^{12}+819 x^{11}-3003 x^{10}-3575 x^{9}+6435 x^{8}+$ $9009 x^{7}-9009 x^{6}-12285 x^{5}+6825 x^{4}+7601 x^{3}-2073 x^{2}-$ $1470 x$ divided by $1260 .{ }^{12}$

\section{On the mathematical features of the Cossic quantities}

Except for Stifel's definition of Cossic numbers, Peter Roth and Johannes Faulhaber, like al-Karajì's school,

${ }^{11} \mathrm{~A} D$-sursolit number is an algebraic number of power 13. Indeed, in the Cossic definition of algebraic powers, the solid number is the third algebraic power, and the sursolit number is the number whose exponent is the first prime exponent after the solid, i.e. the fifth. As Stifel's notation shows, Cossic symbols are then combined with the alphabet letters B, C, D... in order to designate the other prime numbers.

${ }^{12}$ Faulhaber, Academia Algebrae, translated from [3], fol. 15Csi. I have translated the Cossic notation into the modern symbolic language of mathematics. As we can see in Fig. 3, the "minus" symbols are expressed using the symbol of division. For this reason, the authors writes "divided by". I have decided to translate the literal sense, but this actually means that we must subtract (and not divide!) 1260 from the Cossic quantity.

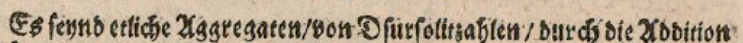
- formiert, in ricjtiger oronung (Darunder gar niobs ausgelailen) auff cinanber folgend / bie uachen zufamen abovert in Suma 70322090. 233ie.

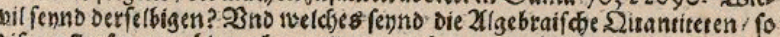

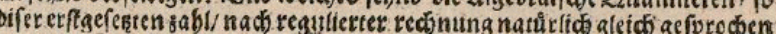

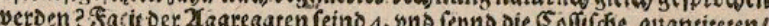
solche begefer soorden / Sife::

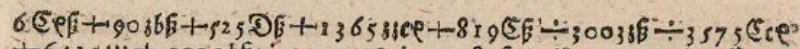
$\rightarrow 6435036+9009 b B \div 9009360 \div 12285 B+68253 j+7601$ हe $\div$ $20732 \div 1470$ gerbeils in 1260 .

Fig. 3. Faulhaber, Academia Algebrae, fol. 15Csi.

lacked an explicit definition of these aggregates. Their focus was on the solution of the equations, and on the collection of problems. Compared to the algebra of sixteenth-century authors, in the seventeenth century the technique for solving algebraic problems became more sophisticated. As shown in the analyses of Schneider and Manders, ${ }^{13}$ Roth and Faulhaber combined algebra with the theory of numbers in order to deal with higher-degree equations. Moreover, they presented several problems involving sums of series of algebraic powers, and transposed into algebra several classes of arithmetical problems, especially those dealing with polygonal numbers. Despite the similarities, the notations adopted in these texts suggest that the expressions conceived by Roth and Faulhaber still differ from the modern notion of the polynomial.

\section{Fictive numbers}

In these problems, Cossic quantities can be of $n$-degree: they do not include the inverse of powers, and negative quantities are still difficult to conceive. However, a new kind of number is mentioned: a number that is fictive (ficta, or gedicht). Inherited from Cardano, this concept is also present in the Cossic writings. In his Book II, Stifel wrote that we can imagine numbers that are less than nothing (finguntur numeri minores nihilo ut sunt 0-3, 0-8, etc.). ${ }^{14}$ In the same way, Roth mentioned the two values of the root -the true one (waaren) and the fictive one (gedicthen) - in problems like the following one:

First, $1 x^{7}+584 x^{4}+17680 x^{3}+18416 x^{2}$ are equal to $7 x^{6}+$ $266 x^{5}+158688 x+174720$. Given now that the value of one true root of this equation is 10 ; then the question is what, which and how many other values of the root, true and fictive, will there be? Answer (Facit): the others are $10+\sqrt{48}, 10-\sqrt{48}$, also -4 and -7 . Thus you see that this equation admits three true and two fictive values of the root. ${ }^{15}$

Fictive numbers do not have the same status as true (i.e. positive) numbers. However, their presence in these texts marks a significant difference in comparison to the Arabic context, in which these quantities are not even conceivable.

\footnotetext{
13 See [8] and [4].

${ }^{14}$ In [9], fol. 48r.

15 Peter Roth, Arithmetica Philosophica, translated in [4], p. 201.
} 
The two case studies presented here show that, as often happens in the history of mathematics, similar questions can arise and similar attitudes can be adopted at different periods. The scholars that we have considered did not focus on the definition of their algebraic expressions because these generic objects were seen as parts of the theory of equations and functional in the resolution of problems. As historians, we can perceive not only that both the Arabic expression and the German Cossic quantity differed from the modern notion of the polynomial, but also that they designated two different objects. In this article, I have only been able to sketch some of their peculiarities: a more detailed analysis will be developed in future work. What already seems clear is that a historical investigation, supported by textual analysis of the sources, of the algebraic expressions that existed before the polynomial contributes to clarifying the process by which the latter was elaborated and bears directly on several significant topics in the history of algebra, such as the resolution of equations through arithmetical methods, the emergence of negative quantities and the introduction of a symbolic language.

\section{Picture credits}

The images in this article are reproduced courtesy of:

- Qistās al-mu'ādala fì 'ilm al-jabr wa'l-muqāaala, Ms. CBL Ar 3927, f.4r, (C The Trustees of the Chester Beatty Library, Dublin.

- Arithmetica integra, authore Michaele Stifelio, cum praefatione Philippi Melanchthonis, apud J. Petreium (Norimbergae), (c) Bibliothèque nationale de France.

- Academia algebrae, darinnen die miraculosische Inventiones zu den höchsten Cossen weiters continuirt und profitiert werden ... Augspurg: bey Johann Ulrich Schönigk, in Verlag Johann Remmelins, 1631. ETHBibliothek Zürich, Rar 3097, https://doi.org/10.3931/erara-16627 / Public Domain Mark.

\section{Refrences}

[1] Salah Ahmad and Roshdi Rashed. al-Bāhir en algèbre d'asSamaw'al. Presses de l'Université de Damas, Damas, 1972.

[2] al-Zanjān̄ī. Qistās al-mu'ādala fı̀'ilm al-jabr wa'l-muqābala. Ms. Dublin, Chester Beatty Library, Arberry 3927.

[3] Johannes Faulhaber. Academia Algebrae. Darinnen die miraculosische Inventionen zu den höchsten Cossischen weiters continuiert und proficiert werden. Johann Ulrich Schönigk, 1631.

[4] Kenneth Manders. Algebra in Roth, Faulhaber and Descartes. Historia Mathematica, (33):184-209, 2006.

[5] Jeffrey Oaks. Polynomials and Equations in Arabic Algebra. Archive for history of exact sciences, 63:169-203, 2009.

[6] Sabine Rommevaux-Tani. Michael Stifel lecteur de la Practica arithmetice de Girolamo Cardano. Bollettino di Storia delle matematiche, (36(1)):83-110, 2016.

[7] Ahmad Salīm Sa'īdān. Tà'rīkh 'ilm al-jabr fì al-'àlam al-'Arabī : dirāsah muqārana ma'a tahqūq li-ahamm kutub al-jabr al-'Arabīya [History of Algebra in medieval Islam. A comparative study, with the edition of the most important books of Arabic algebra], volume 1 Algebra in Eastern Islam: study built upon Al-Fakhrī of Al-Karajī . National Council for Culture, Art and Letters. Department of Arab Heritage, 1986.

[8] Ivo Schneider. Johannes Faulhaber 1580-1635, Rechenmeister in einer Welt des Umbruchs. Birkhäuser, 1993.

[9] Michael Stifel. Arithmetica Integra. apud J. Petreium, 1544.

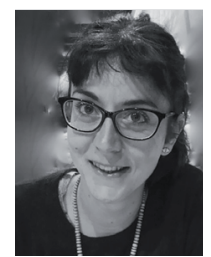

Eleonora Sammarchi [eleonora.sammarchi@gmail.com] holds a doctorate in epistemology and history of sciences and technologies, and is an associate researcher in the laboratory SPHERE, UMR 7219, Université Paris Diderot, Paris, France. Her main interests concern medieval Arabic mathematics, and in particular medieval Arabic algebra and arithmetics. She is also interested in the history of algebra in early modern times. 